\title{
Branchless Banking Process in Rural Areas: A Price Barrier?
}

\author{
Ktut Silvanita Mangani \\ Dept. of Magister Management, Universitas Kristen Indonesia \\ J1. Pangeran Diponegoro 84-86, Jakarta, Indonesia
}

Adolf Bastian Heatubun

Dept. of Magister Management, Universitas Kristen Indonesia

Jl. Pangeran Diponegoro 84-86, Jakarta, Indonesia

Martua Eliakim Tambunan

Dept. of Magister Management, Universitas Kristen Indonesia

Jl. Pangeran Diponegoro 84-86, Jakarta, Indonesia

Received: May 9, $2021 \quad$ Accepted: June 15, $2021 \quad$ Online published: June 28, 2021
$\begin{aligned} & \text { doi:10.5296/jpag.v11i2.18816 } \quad \text { URL: https://doi.org/10.5296/jpag.v11i2.18816 }\end{aligned}$

\begin{abstract}
Branchless Banking is one of the programs of Indonesia's financial inclusion strategy. The programs' name is "Financial Service Without Office in the Framework of Inclusive Financial" which called "Laku Pandai." This study aims to portrait the implementation of the Branchless Banking program concerning the obstacles that occurred to achieve program objectives. The research conducted using qualitative methods. The existence of Branchless Banking agents close to the community has fulfilled the program objective, to make an easy way for society to do financial transactions without having to go to the bank office. Therefore, the implementation of the Branchless Banking program met the criteria for eliminating non-price barriers in financial services in remote areas. However, delegation authority to the agent as an extension of the bank to provide limited financial services has encouraged agents to engage in moral hazard behaviors by charging the tariff that greater than the official rate set by the managing bank. It showed that the agent has taken the consumer surplus provided by the Branchless Banking technology. Although accepted by society since considerably
\end{abstract}


cheaper than the fee to go to the nearest bank office, that condition becomes a price barrier for the future development of Branchless Banking.

Keywords: branchless banking, financial inclusion, moral hazard, consumer surplus, price barrier

\section{Introduction}

\subsection{Financial Inclusion and Branchless Banking}

Financial inclusion is a process that encourages ownership of bank accounts by each household and offers their participation in the banking system. As a significant player in financial institutions, banks can distribute opportunities equally, including those who live in remote areas, so they can access financial services such as saving, paying bills, transferring, borrowing credit, and other financial services (Aduda \& Kalunda, 2012). Financial inclusion is an antithesis of financial exclusions, the inability to get access to financial services needed in an appropriate form (Carbo et al., 2005; Sanjaya, 2014). The exceptions will have an uneven impact on economic growth because it creates income differences and increases inequality.

In 2012, Indonesia launched the National Financial Inclusion Strategy (SNKI). Its vision is to create a financial system accessible to all levels of society to promote economic growth, poverty alleviation, equity distribution, and the creation of financial stability. SNKI has six pillars: 1) Financial Education, 2) Public Financial Facilities, 3) Mapping Financial Information, 4) Supporting Policies/Regulations, 5) Intermediary and Distribution Facilities, and 6) Protection Consumer (Bank Indonesia [BI], 2019). Branchless banking is a program included in the fifth pillar, Intermediary, and Distribution Facilities. It aims to increase awareness of financial institutions about the existence of potential segments in society and expand the reach of financial services using alternative distribution methods. The Consultative Group to Assist the Poor (CGAP), a global partnership with 34 world-leading organizations striving to improve Financial Inclusion define Branchless Banking as financial services outside conventional bank branches using communication and information technology, agents, and card-based networks or by using cell phones (Pickens et al., 2009).

Branchless Banking is a vehicle that provides banking services to the customer's doorstep as an innovation from the traditional approach where customers are looking for a bank. Branchless Banking defined as financial services to the public using information technology (Ivatury \& Mas, 2008). This type of Branchless Banking is called transformational Branchless Banking, which aims to reach and provide the financial service to people who do not have yet a bank account (unbanked people). It explained that there are several elements of Branchless Banking:

1. Technology, such as debit/credit cards and cellular phones,

2. Third parties, post offices or agents,

3. Provides at least a simple savings account product (Basic Saving Account), in addition to payment services, and

4. Supported by government and banking regulations. 


\section{Mll Macrothink}

Journal of Public Administration and Governance

ISSN 2161-7104

2021, Vol. 11, No. 2

Some research revealed that Branchless Banking is a cost-effective solution for providing financial services for people who live in remote places compared to opening conventional branch offices (Ivatury \& Mas, 2008; Khattab et al., 2012; McKay \& Pickens, 2010). The cost of essential banking services with Branchless Banking is at least 50 per cent lower than the costs incurred to serve them through traditional channels. In the Philippines, cash deposits or withdrawals made through bank office charged $\$ 2.50$, while the same transaction via mobile phone costs $\$ 0.50$ only. With Branchless Banking technology, customer benefits shorter travel and waiting times, as well as low transportation costs since they are close to the agent's place and do not need to queue like in a bank office. It shows that Branchless Banking is a good financial technology to reach those that are still unbanked especially in rural areas. Therefore, how its implementation in the field needs to be known, especially its barriers.

\subsection{Significance of the Study}

Research by Arnold and Rhyne (2016) explains that successful financial inclusion requires financially capable consumers who actively use financial service for their benefit. The number of the first new customers grew rapidly came from traditional customers, that is underserved segments of the population. They potentially use formal financial services. The research supports a branchless banking program idea - a banking service provided to the customers without having to come to a bank office - that is, using services from a third party or agent. The program carries out an intermediary function to provide access to financial services for the poor, migrants, and other target community groups.

The Financial Service Authority of Indonesia called the branchless banking program as "Laku Pandai-financial service without office in the framework of inclusive finance-," namely the provision of banking or other financial services in cooperation with other parties (bank agent), and supported by the use of information technology facilities. The program aims to provide financial products that are simple, easy to understand, and fits the needs of people who have not been able to reach financial services. Besides, it will also accelerate community economic activities to encourage economic growth and equitable development between regions in Indonesia, especially between villages and cities (Otoritas Jasa Keuangan [OJK], 2015). The products provided in this program include savings with the characteristics of a Basic Saving Account (BSA), credit or financing to micro customers, and other financial products such as Micro Insurance. "Laku Pandai" agents spread across 34 Provinces in Indonesia and the highest is in Jawa Barat (West Java), as shown in Figure 1. 


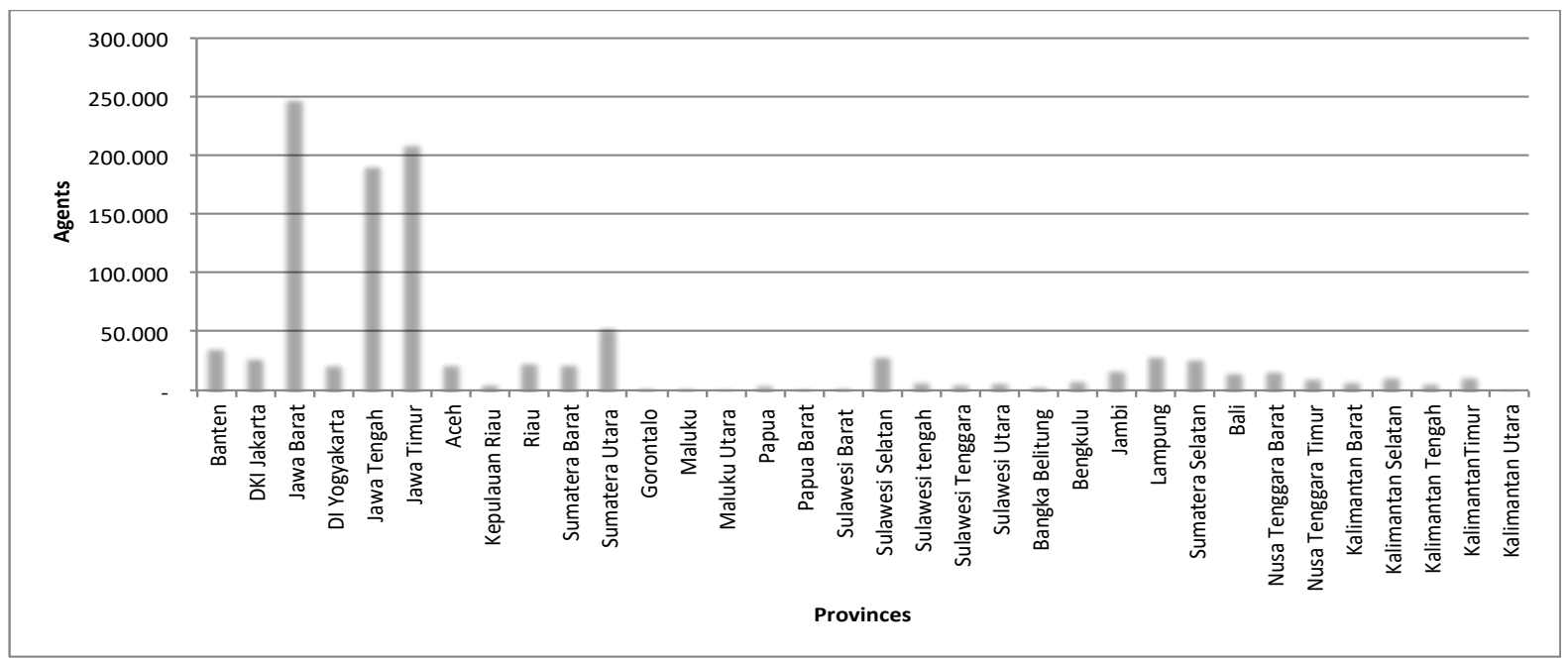

Figure 1. Distribution of Bank Agents by Provinces in Indonesia (OJK, 2019)

The spread of Branchless Banking agents in almost all regions of Indonesia show that the process of implementing the Inclusive Financial Strategy policy has been running. Furthermore, the process of implementing the Branchless Banking program will determine the success of the objectives set, to achieve the target the availability access financial services to all, especially in remote areas. A case study of the implementation of the branchless banking program in Bogor Regency in years 2016 - 2017 shows the establishment of agent units indicates that the program has not provided maximum performance (Mangani et al., 2019a, 2019b). The results of the study raise a fundamental question of how to achieve the success of the national financial inclusion strategy in the future. This research aims to answer whether the implementation of the program has run according to the function of a financial inclusion strategy, namely to eliminate price and non-price barriers to financial access.

\subsection{Literature Review}

\subsubsection{Principal-Agent Problem}

In a contract between two parties - in this study is a contract between the bank as the branchless banking program organizer and the individual in the society as an agent - there exists asymmetrical information. Theoretically, asymmetric information results in adverse selection behaviour that takes place before the transaction, and moral hazard behaviour after the transaction (Akerlof, 1998).

In the relationship between the principal and agent, there exist delegation of the task in which the agent carries out the responsibility of completing work according to the principal's goals. However, in practice, the principal cannot monitor the agent's activities perfectly, while the agent has more information about the conditions in the field. Such asymmetric information conditions can lead to negative agent behaviours, called moral hazard, in which the agent is prioritizing more on its benefit by doing a hidden violation and harming the principal. "moral hazard refers to the tendency of an agent, after the contract is entered into, to shirk or otherwise not fully seek to promote the principal's interests" (Halim \& Abdullah, 2006; Petrie, 


\section{Macrothink}

Journal of Public Administration and Governance

ISSN 2161-7104

2021, Vol. 11, No. 2

2002). However, the moral hazard that arises in the principal-agent relationship may occur without the initiation of such behaviour but triggered by opportunities or leeway in the rules. Therefore, adequate incentives are needed to encourage the agent to work following the goals desired by the principal. Moral hazard behaviour may be preceded by adverse selection behaviour before the contract. Before the contract, the agent chose to hide some information that not desired by the principal. However, this study is focusing on the problem of moral hazard behaviour of agents.

In serving the financial transactions in remote areas, the bank institution recruits agents, who domiciled around the target communities. The agent provides limited financial services such as savings, cash withdrawals, transfers, and other financial transactions such as serving the purchase of electronic pulses, water, electricity, and other obligations. The Bank monitors the agent's transactions through online report.

\subsubsection{Consumer Surplus}

The social value of the existence of branchless banking technology can be carried out with an economic approach. Value is determined by the community's willingness to make trade-offs, where the willingness to pay people to make trade-offs is reflected by the public's willingness to pay for goods and/or services at a money price. Willingness to pay is the maximum amount someone wants to sacrifice in a certain monetary value to obtain goods and/or services.

In the branchless banking context, the basic concept used is consumer surplus. Consumer surplus occurs when the maximum amount that consumers are able to pay is greater than the amount to be paid to obtain goods or services. Consumer surplus reflects the measurement of welfare at the consumer level which is measured by the difference between willingness to pay with the amount he actually has to pay (Mankiw, 2014). Consumer surplus can also be expressed as a condition in which the consumer is willing to pay higher than the equilibrium price, as shown in Figure 2.

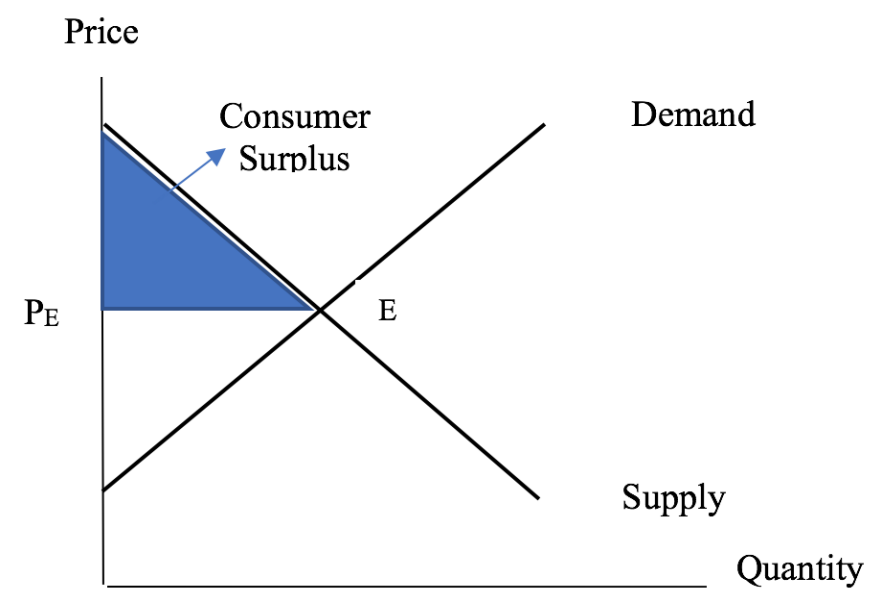

Figure 2. Consumer Surplus

\subsection{Hypotheses}




\section{Ml Macrothink}

Journal of Public Administration and Governance

ISSN 2161-7104

2021, Vol. 11, No. 2

Based on the background and literature review, this study aims to explore the problems that arise in the implementation of branchless banking in rural areas. Since the Branchless Banking program practices the delegation of limited duties from the bank to the agent, it is hypothesized that bank agents practice moral hazard. The behavior is a deprivation of the consumer surplus of rural communities that receive banking access facilities from the government through the branchless banking program. That behavior can become a barrier to the development of the branchless banking program.

\section{Method}

The study conducted 6 (six) months in 2019 in Sumedang Regency, West Java Province, Indonesia. As shown in Figure 1, West Java Province has the highest number of agents compared to other provinces in Indonesia. This research is descriptive - qualitative. The "social situation" is the state of branchless banking financial services. The informants or resource persons were the agents and clients involved in the program. The data collection carried out using participant observation techniques, in-depth interviews, documentation studies, and triangulation

Observation is conducted by observing the object and process to obtain information about the behavior and its meaning. The observation technique used is participatory observation i.e. the researcher involved in the branchless banking activity of the respondent (agent) and observing its behavior. The observation stages are (1) passive participatory observation, (2) moderate participatory observation, (3) active participatory observation, and (4) complete participatory observation. Therefore, the data collected becomes complete, sharp, and the meaning is known.

An interview conducted to exchange information and ideas so that the meaning can be reconstructed from the process. Documents recorded are the events that have occurred in the form of writings, drawings, or monumental works from the informants. Afterwards, to increase researchers' understanding of information found then is done the triangulation process through a combined technique in data collection (observation, interviews, and documents). Finally, the Miles and Huberman analysis technique is used based on principal-agent theory as well as the criteria and requirements of the inclusive financial strategy set by Bank Indonesia (Gorman et al., 2005; Sugiyono, 2013).

There are 26 sub-districts in Sumedang Regency. This study conducted in-depth interviews with 28 informants from 13 sub-districts, namely Pamulihan, Sumedang Selatan, Jatinunggal, Cimanggung, Sumedang Utara, Tanjung Medar, Sukasari, Darmaraja, Tanjungkerta, Jatinangor, Tomo, Cisarua, and Cibugel, as shown in Figure 3. 


\section{Macrothink}

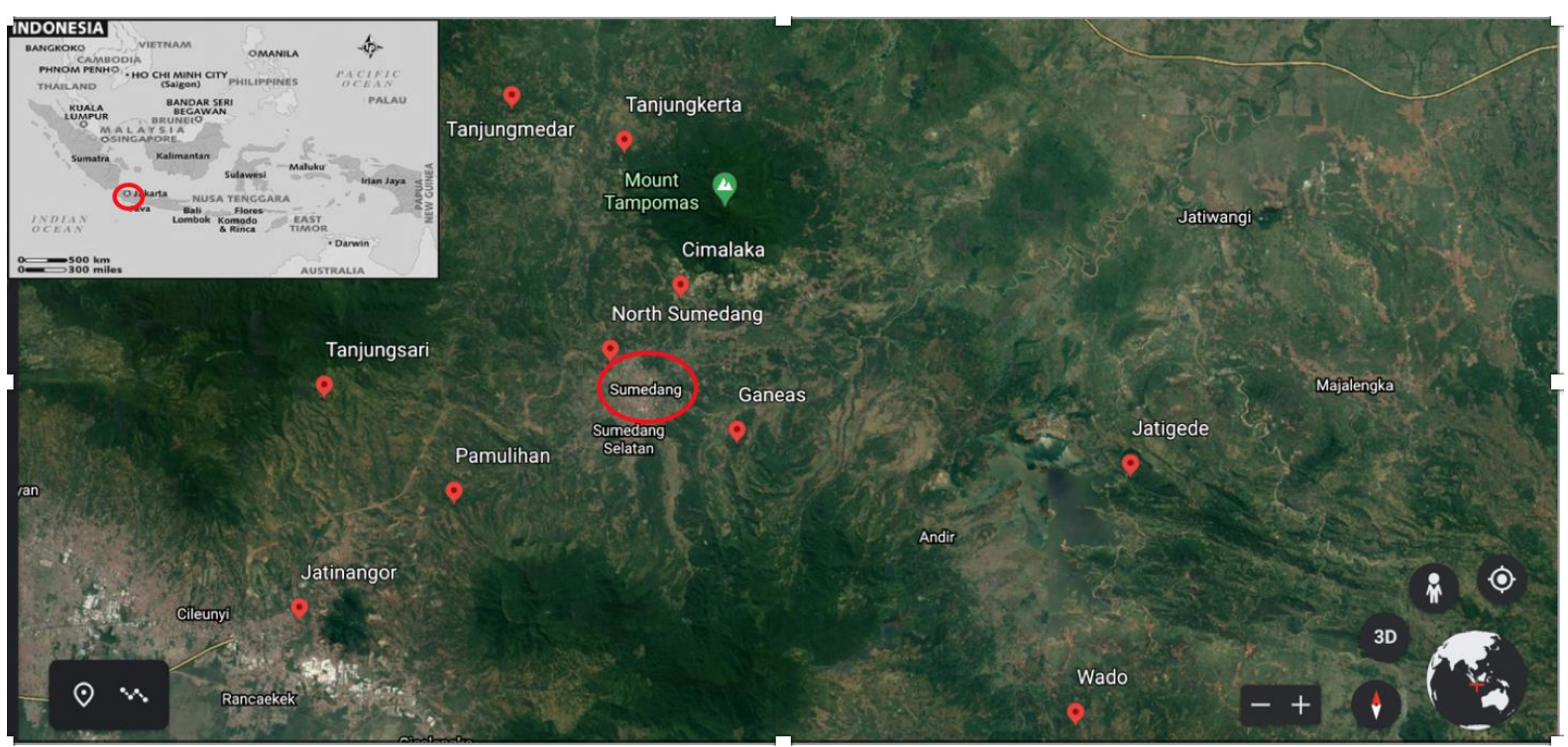

Figure 3. Map of the study area in Sumedang District, West Java, Indonesia

(Source: Google earth)

\section{Results}

\subsection{Types of Agent's Business}

Branchless banking agents in Sumedang Regency generally operate in suburban areas serving public financial transactions. While in the downtown area, they served by the Bank Unit Office. Table 1. presents data on the agent's identity: its business, and the distance between its location and the capital city of Sumedang Regency. 


\section{Ml Macrothink}

Journal of Public Administration and Governance

ISSN 2161-7104

2021, Vol. 11, No. 2

Table 1. Type of business, Distance from the City Centre, and No of Transactions

No Agent's Store Name

Type of Business

Daily

Distance $(\mathrm{km}) \quad$ Transactions

Monthly Min. Max.

\begin{tabular}{cllcccc}
\hline 1 & Toko Wina & Fabric store & 17.80 & 10 & 20 & 375 \\
\hline 2 & Ihsan Fotocopy & Photocopy shop & 7.20 & 10 & 22 & 400 \\
\hline 3 & Agen Sapong Atang & Agriculture shop & 51.30 & 10 & 20 & 375 \\
\hline 4 & Pauzan Store & Grocery store & 45.90 & 30 & 20 & 1,000 \\
\hline 5 & Toko Samiyati/ Tantrem & Water gallon refill \& Grocery store & 24.90 & 15 & 50 & 500 \\
\hline 6 & Toko 62 & Grocery store & 3.90 & 10 & 25 & 425 \\
\hline 7 & Zain Cell & Grocery store & 18.80 & 10 & 25 & 375 \\
\hline 8 & Ansa Abi'el 2 Jaya & Grocery store & 25.20 & 15 & 20 & 425 \\
\hline 9 & Simphoni Komunika & Grocery store & 48.90 & 15 & 20 & 425 \\
\hline 10 & Warung Dhany & Grocery store & 1.80 & 10 & 20 & 425 \\
\hline 11 & Warung Iin & Wholesaler & 22.70 & 10 & 30 & 500 \\
\hline 12 & Naufal Cell & Cellular Credit top-up & 27.10 & 10 & 15 & 300 \\
\hline 13 & Kios Agis Kosh & Cellular Credit top-up & 10.60 & 15 & 25 & 500 \\
\hline 14 & Toko Deden & Grocery store & 6.00 & 15 & 25 & 500 \\
\hline 15 & Agen Marikun & Grocery store & 28.90 & 15 & 20 & 425 \\
\hline 16 & Toko Rizky & Furniture & 14.70 & 10 & 20 & 375 \\
\hline 17 & Warung Dinda & Cellular Credit top-up & 1.60 & 10 & 20 & 375 \\
\hline 18 & Toko Raihan & Grocery store & 25.70 & 15 & 25 & 500 \\
\hline 19 & Toko Winna & Wholesaler & 32.70 & 15 & 20 & 450 \\
\hline 20 & Toko Shafa & Grocery store & 1.70 & 15 & 30 & 550 \\
\hline 21 & Yoes Aksesories & Accessories shop & 4.90 & 10 & 20 & 375 \\
\hline 22 & Toko Ririn & Stationery shop & 5.40 & 15 & 25 & 500 \\
\hline 23 & Toko Adang & Minimart & 28.00 & 20 & 30 & 625 \\
\hline 24 & Toko Li Rustan & Minimart & 40.20 & 10 & 20 & 375 \\
\hline 25 & Toko Galeri Busana & Cloth shop & 20.00 & 5 & 20 & 300 \\
\hline 26 & Toko Antasalam & Grocery store & 23.20 & 10 & 40 & 625 \\
\hline 27 & Toko Andriani & Grocery store & 26.20 & 10 & 50 & 750 \\
\hline 28 & Toko Salsabila & Grocery store & 23.00 & 10 & 15 & 300 \\
\hline & & & & & & \\
\hline
\end{tabular}

Table 1. shows that the majority of agents $(82.14 \%)$ operate in Sumedang City suburbs, and $17.86 \%$ operate in the rural which quite far from the city centre. Agents conduct the financial services in their place of business that has been existing. Not on the plan or relocation by the bank unit for a particular purpose. Each branchless banking agent is an entrepreneur that has owned a specific business unit before becoming an agent. Therefore, it said that the agents are business actors who have capital. It corresponds to the expectations of the bank unit as a principal, in which the prospective agents must have operational capital when becoming an agent to facilitate the financial transactions by the customers.

The interview results explain that the bank unit recruits prospective agents based on the fact 
that the candidate has become a customer of its bank unit. They must have a certain amount of savings in its bank account, a business unit that has been verified, and an achievement as a 'good' customer. It shows that the recruitment criteria for the prospective agent based on the bank's criteria but does not focus on a specific type of the product to be developed in the program's target area. Thus, it concludes that the branchless banking program implemented by the bank institution focused more on the occurrence of financial transactions.

\subsection{Transaction Process}

Branchless banking agents offer limited banking services, such as receiving deposits, cash withdrawals, facilitating the transfer of money between the same banks or other banks (different provider). It also provides bill payment services such as electricity bill payment, water bill payment, as well as selling cellular voucher and prepaid electricity voucher.

Each agent equipped with an EDC (Electronic Data Capture) device, as well as some supporting tools, namely cell-phone sim card, transaction paper, charger, and transaction fee list. As an official agent, it also equipped with the certificate, and/or identity card, as well as a banner. In terms of sim card, they choose a provider with the best signal condition and a high number of users in that location. Some agents are equipped with two types of cards from different providers. It aims to avoid or reduce the occurrence of fail transactions due to an unstable signal. As an agent, they have obligations and rights. An agent must serve customers who want to conduct financial transactions by using an EDC machine. For transaction needs, the agent must have sufficient funds, both cash and funds in a savings bank account. When the customer wants to withdraw his/her savings, the customer has to transfer his funds to the agent's account by swiping its ATM cards through the EDC machine. In that way, the agent's account increases and the customer's account decreases. Furthermore, the agent will give cash to the customer as much as the funds transferred. Conversely, if the customer wants to increase his/her savings balance, the agent will receive the cash from the customer. Then the agent will transfer a certain amount of funds to the customer's account, using the agent's ATM card and through the EDC machine. Thus, the agent's account balance will decrease but turn into cash. To prove that the transaction was successful, then the customer needs to check his balance account by swiping his card using the EDC machine. For those transactions, the customer has to pay a fee as a transaction service according to the applicable tariff.

The customer can do transfer to other bank or between bank using their ATM cards through the EDC machine. In this case, there is no change in the savings and cash account agent. Through the agent, a customer can also transfer by cash. After receiving cash from the customer, the agent does transfer to the customer's designated account using his ATM through EDC machine. Thus, the agent's account balance reduces as much as cash received from the customer. Mechanisms for changes in cash balances and agent accounts can also occur for online payment and purchase transactions made by customers through its EDC machine. The process shows the financial transactions that carried out on the branchless banking program is using the agent's fund both in cash and in its banking account. Therefore, the agent must have sufficient funds and must be able to balance its cash and funds in his bank account. If an agent holds an excessive cash, then he will go to the bank office to save it. Conversely, if he 
predicts that the existing cash is not enough to serve daily financial transactions, the agent must go to the bank's office to withdraw their savings.

The existence of the agent in the community in Sumedang Regency received a good response from them. It indicates by the number that is $89.29 \%$ of agent respondents have 10 to 15 transactions per day or 300 to 450 transactions per month (see Table 1). The number of transactions has met the minimum criteria set by the managing bank, which is 250 transactions per month. It shows the success of the program, based on the number of transactions targets set.

\subsection{Moral Hazard Behavior: A Price Barrier?}

Agency theory explains the relationship between the principal and agent in a cooperation contract. The principal as job owner delegates authority to the agent to carry out the responsibility of completing the work according to the objectives desired by the principal. Both parties can lead to the same goal, but not always have the same interests. The principal cannot monitor the agent's activities perfectly so that the incentives needed to encourage the agent to work according to the objectives desired by the principal. On the other hand, agents can be more concerned with their interests which can harm the principal (Consultative Group to Assist the Poor [CGAP], 2019).

The field finding show that the cooperation contract between the agent and the bank unit as the principal has run. The agent is doing his job as desired by the principal. One of the targets set by the principal is that each agent has to achieve a minimum number of transactions, i.e. 250 transactions per month. When the agent does not reach that number than the principal will provide sanction in the form of "revocation of the agent's operating license." For financial services provided by agents to customers, the bank gives incentives or commissions for every transaction made using EDC machines. A commission is in the form of a $50 \%$ refund of administrative costs for each transaction service using the agent's ATM card. In other words, banks only charge 50\% of bank administration fees for each transaction through the agent's EDC machine. On the other hand, to cover the cost, the agent receives payment from the customers for each transaction service at a rate determined by the bank. However, the information obtained that has confirmed by the triangulation method, found agents charge different fees that higher than the official rate set by the branchless banking managing bank. The average tariff for each transaction and the calculation of the mark-up and its percentage shown in Table 2. 
Table 2. Tariff and mark-up

\begin{tabular}{|c|c|c|c|c|c|}
\hline No. & Types of transaction & $\begin{array}{l}\text { Official tariff } \\
\text { (Rp) }\end{array}$ & $\begin{array}{l}\text { Average tariff } \\
\text { charged (Rp) }\end{array}$ & Mark-up (Rp) & Percentage \\
\hline 1 & Balance info of Bank-X & 0 & 3,000 & 3,000 & 100 \\
\hline 2 & Balance info of other bank & $3,000(\mathrm{n} / \mathrm{a})$ & - & - & - \\
\hline 3 & Electricity payment & 3,000 & 8,000 & 5,000 & 167 \\
\hline \multirow{3}{*}{4} & Transfer with customer's card & & & & \\
\hline & -To Bank-X & 3,000 & 18,000 & 15,000 & 500 \\
\hline & -To other bank & 3,000 & 18,000 & 15,000 & 500 \\
\hline 5 & Cash deposit & 3,000 & 18,000 & 15,000 & 500 \\
\hline 6 & Cash withdrawal & 3,000 & 18,000 & 15,000 & 500 \\
\hline \multirow{4}{*}{7} & Cash transfer: & & & & \\
\hline & -To Bank-X & 3,000 & 18,000 & 15,000 & 500 \\
\hline & -To other bank & 6,500 & 26,500 & 20,000 & 308 \\
\hline & Average & 3,050 & 14,350 & 11,300 & 341 \\
\hline
\end{tabular}

Source: Authors' calculations (Note: 1 USD = Rp 14,081.3 as of 31 November 2019)

Every customer who conducts financial transactions through an agent must pay an administration fee at the official rate set by the managing bank, which is Rp. 3,000 to Rp. 6,500. However, field data show that the customers do not only pay an administration fee but also subject to an additional fee (mark-up). Table 2 shows that the amount of mark-up varies between Rp.3,000 to Rp.20,000 per transaction. On average, the agent charged Rp.11,300 or $341 \%$ of mark-up for each transaction.

Mark-up performed by an agent to the customers is called moral hazard behaviour, namely hidden behaviour that not reported to the bank as the principal to maximize its profit. The agent considers the mark-up fee is reasonable. On the other hand, the customer generally accepts the tariff since the transportation cost to go to the nearest bank office are relatively the same. This condition shows that the consumer surplus occurs from the existence of branchless banking technology in the vicinity of the community/customer residence has been taken by the agent.

Based on the information obtained from respondents, the bank unit as the principal does not respond regarding the mark-up made by the agent. The principal is more focused on the target minimum number of transactions that must be achieved by each agent. Thus, within the scope of financial inclusion development that aims to improve the financial services to all people conveniently and cheaply; the customers in Sumedang Regency have obtained the convenience services. They can fulfil their financial transactions through an agent that close to their place. In this regard, the implementation of the branchless banking program has removed non-price barriers. The results of the study support the statement of Ivatury (2008), Khattab (2012), and McKay (2010), that customers benefit from branchless banking technology due to shorter travel and waiting times, and low transportation cost. However, moral hazard behaviour conducted by the agent made the Branchless Banking services becomes expensive for customers in remote areas. In that case, the transportation fee to the 
nearest unit bank office simply switches to the status of mark-up fee. Thus, the benefits obtained by the community by having Branchless Banking in their area have been utilized by agents. It explains that the agent has taken the consumer surplus of the customers. Therefore, the implementation of Branchless Banking unable to remove the price barrier to reach people in remote areas. Such conditions show the potential to create failure in the implementation of financial inclusion.

\section{Conclusion}

Financial inclusion services through the implementation of the branchless banking program have been running well in Sumedang Regency. The number of transactions that occurred at the agents has met the transaction target set by the managing bank. However, types of activity and the location of agents shows the selection of agents did not focus on developing a specific product as an effort to encourage economic growth in remote areas according to the objective of National Strategy for Financial Inclusion.

The existence of branchless banking agents close to the community has fulfilled the program's objective, to make an easy way for the society to conduct financial transactions without having to go to the bank office. Then, the implementation of the Branchless Banking program met the criteria for eliminating non-price barriers in financial services in remote areas.

It was proven that the proximity of branchless banking agents to the surrounding community reduces transportation costs. However, the delegation of authority to the agent as an extension of the bank to provide limited financial services to the society in rural areas has encouraged agents to engage in moral hazard behaviour by charging the tariff that greater than the official rate set by the managing bank. Although accepted by society since it is still considerably cheaper than the fee to go to the nearest bank office, that condition becomes a price barrier for the future development of Branchless Banking. Therefore, the statement of Ivatury (2008), Khattab (2012), and McKay (2010), that Branchless Banking is a cost-effective solution for providing financial services for people living in remote areas needs to be reviewed in some different areas.

\section{References}

Aduda, J., \& Kalunda, E. (2012). Financial inclusion and financial sector stability with reference to Kenya: A review of literature. Journal of Applied Finance and Banking, 2(6), 95.

Akerlof, G. A. (1998). THE MARKET FOR" LEMONS": QUALITY UNCERTAINTY AND THE MARKET MECHANISM. Economic Analysis of Contract Law, Antitrust Law, and Safety Regulations, 2, 2.

Arnold, J., \& Rhyne, E. (2016). A Change in Behavior: Innovations in Financial Capability. Centre for Financial Inclusion.

Bank Indonesia. (2019). Booklet Keuangan Inklusif Bank Indonesia. Retrieved March 4, 2019 from https://www.bi.go.id/id/perbankan/keuanganinklusif/\%20edukasi/\%20Contents 


\section{I Macrothink}

Journal of Public Administration and Governance ISSN 2161-7104

Carbó, S., Gardener, E. P., \& Molyneux, P. (2005). Financial Exclusion in Developing Countries. In Financial Exclusion (pp. 145-168). Palgrave Macmillan, London. https://doi.org/10.1057/9780230508743_8

Consultative Group to Assist the Poor. (2019). Advancing Financial Inclusion to Improve the Lives of the Poor. Retrieved March 4, 2019 from http://www.cgap.org/about

Gorman, G. E., Clayton, P. R., Shep, S. J., \& Clayton, A. (2005). Qualitative research for the information professional: A practical handbook. Facet Publishing. https://doi.org/10.29085/9781856047982

Halim, A., \& Abdullah, S. (2010). Hubungan dan Masalah Keagenan di Pemerintah Daerah. Jurnal Akuntansi Pemerintah, 2(1), 53-64.

Ivatury, G., \& Mas, I. (2008). The early experience with branchless banking. CGAP Focus Note, (46).

Khattab, I., Balola, Y., \& Eldabi, T. A. (2012). Factors influencing branchless banking for microfinance in Sudan: Theoretical perspectives and future directions.

Mangani, K. S., Syaukat, Y., Arifin, B., \& Tambunan, M. (2019a). THE ROLE OF BRANCHLESS BANKING IN PERFORMANCE OF HOUSEHOLDS'MICRO AND SMALL ENTERPRISES: THE EVIDENCE FROM INDONESIA. Economics and Sociology, 12(3), 114-131. https://doi.org/10.14254/2071-789X.2019/12-3/8

Mangani, K. S., Syaukat, Y., Arifin, B., \& Tambunan, M. (2019b). Implementation of Branchless Banking in Bogor: a Figure of New Financial Service in Rural Area. Jurnal Aplikasi Bisnis dan Manajemen (JABM), 5(1), 131-131. https://doi.org/10.17358/jabm.5.1.131

Mankiw, N. G. (2014). Principles of economics. Cengage Learning.

McKay, C., \& Pickens, M. (2010). Branchless banking 2010: Who's served? At what price? What's next? CGAP Focus Note, (66).

Otoritas Jasa Keuangan. (2015). Laporan Kinerja OJK 2015. Retrieved March 4, 2019 from: https://www.ojk.go.id/id/berita-dan-kegiatan/publikasi/Documents/Pages/laporan-kinerja-ojk2015/FA_Laporan\%20kinerjaOJK201rev070116_II.PDF

Otoritas Jasa Keuangan. (2019). Statistik Perkembangan Laku Pandai. Retrieved March 4, 2019 from: https://www.ojk.go.id/id/pages/Laku-Pandai.aspx

Petrie, M. (2002). A framework for public sector performance contracting. OECD Journal on Budgeting, 1(3), 117-153. https://doi.org/10.1787/budget-v1-art18-en

Pickens, M., Porteous, D., \& Rotman, S. (2009). Focus Note: Scenarios for Branchless Banking in 2020. CGAP and Department for International Development, London.

Sanjaya, I. M. (2014). Inklusi keuangan dan pertumbuhan inklusif sebagai strategi pengentasan kemiskinan di Indonesia Bogor: Institut Pertanian Bogor. 
Sugiyono. (2013). Metode Penelitian Gabungan (Mixed Method). Alfabeta, Bandung.

\section{Copyright Disclaimer}

Copyright for this article is retained by the author(s), with first publication rights granted to the journal.

This is an open-access article distributed under the terms and conditions of the Creative Commons Attribution license (http://creativecommons.org/licenses/by/4.0/). 